\title{
Effect of Rootstock on Rooting and Early Yield of Stenting-propagated Cut Roses
}

\author{
Yoo Gyeong Park ${ }^{1,2}$ and Byoung Ryong Jeong ${ }^{1,2,3^{*}}$ \\ ${ }^{1}$ Division of Applied Life Science (BK21 Plus), Gyeongsang National University, Jinju 660-701, Korea \\ ${ }^{2}$ Institute of Agriculture \& Life Science, Gyeongsang National University, Jinju 660-701, Korea \\ ${ }^{3}$ Research Institute of Life Science, Gyeongsang National University, Jinju 660-701, Korea
}

\begin{abstract}
The study was conducted to investigate the effect of rootstock on growth and early yield of stenting-propagated cut roses (Rosa hybrida Hort.) 'Pink Aurora' and 'Yellow King'. The scions, prepared as single-node cuttings, each with a five-leaflet leaf, were grafted onto cuttings of Rosa indica 'Major', Rosa multiflora 'Chille Wonye No. 1', Rosa multiflora 'K-1', or Rosa multiflora 'Burr' as the rootstock. The rootstock cuttings were removed of all leaves and buds before grafting. The base of scion and the top of rootstock were held together and simultaneously cut at a $45^{\circ}$ angle for ease of grafting. Scion-rootstock unions were stuck in rockwool cubes and placed on a misted glasshouse bench for rooting before being transplanted into a rockwool slabs for cultivation. Rooting was the greatest in the 'Pink Aurora' and 'Yellow King' grafted on the rootstock Rosa indica 'Major'. In 'Pink Aurora', stem length, stem diameter, five-leaflet leaves per stem, and stem fresh weight of the harvested cut flowers were not affected by the rootstock. The greatest total yield of 'Pink Aurora' was obtained in plants grafted onto the Rosa indica 'Major' rootstock. Overall growth of 'Yellow King' was the greatest in plants grafted onto Rosa multiflora 'Burr' rootstock, although total yield was not affected by the rootstock. These results suggest that Rosa indica 'Major' is the most effective rootstock not only for rooting, but also for early yield and growth for stenting propagation of these cut roses.
\end{abstract}

Additional key words: graft-take, Rosa indica 'Major', Rosa multiflora 'Burr', Rosa multiflora 'Chille Wonye No. 1', Rosa multiflora 'K-1'

\section{Introduction}

The stenting (= grafted cutting) method as an efficient technique of propagation has many advantages as reported by Ohkawa (1980) and van de Pol and Breukelaar (1982), and is now being used worldwide by many rose growers. Stenting propagation has been practiced in some nurseries as a substitute for budding, since it has advantages such as higher yield and quality, and the same resistance to the crown gall disease (Park and Jeong, 2010a). Despite these advantages of stenting propagation for cut roses, there have been some limited number of studies (Park and Jeong, 2010a, 2010b, 2012a, 2012b) on this method and it has not been widely used due to difficulty and inefficiency of this important propagation method. For development of an efficient propagation method we need to establish the proper rootstock selection for stentingpropagated cut roses which require high quality and yield.

Rootstock use has been based on the observation that performance and flower productivity in grafted plants is higher than those in plants growing on their own roots (Cabrera, 2002; Hanan and Grueber, 1987). Raviv et al. (1993) suggested that for each rose cultivar, rootstock clones should be selected to ensure highest productivity. Safi (2005) reported that regardless of as rootstock type, the three cultivar-rootstock combinations were superior to the own-rooted plants for yield and re-blooming time required. Different rootstocks are recommended in various

\footnotetext{
*Comesponding author: brjeong@gmail.com

※ Received 27 February 2014; Revised 10 September 2014; Accepted 23 September 2014. This study was carried out with the support of "On-Site Cooperative Agriculture Research Project (Project No. 006330)", RDA, Republic of Korea. Yoo Gyeong Park was supported by a scholarship from the BK21 Plus Program, the Ministry of Education and Human Resources Development, Republic of Korea.

(C) 2015 Korean Society for Horticultural Science
} 
areas in the world based on regional differences in climate and soil conditions, in addition to the consideration of rootstock and scion compatibility (Niu and Rodriguez, 2008).

The rootstock Rosa indica 'Major', also known as Rosa odorata or Rosa chinensis 'Major', prefers warm climates, with slightly sandy soils and a medium-high pH (6.5-7.5). Because of these characteristics, it is still predominantly used in such Mediterranean areas as Italy, South of France, Spain, Turkey, Morocco etc. (Gerardo, 2007). It is propagated vegetatively as the previously mentioned 'Natal Briar' and for this reason the parent plants have to be replaced at regular intervals with disease-free, tissue cultured plants from laboratory. The rootstock Rosa multiflora has strong vigor with no winder dormancy, and produces many misshapen flowers (Gerardo, 2007).

Earlier and recent comparative studies on rose rootstock performance have shown variable results, undoubtedly due to a myriad of factors, including a multitude of scion-rootstock combinations, rootstock clonal effects, type and depth of growing medium (soil and soilless), length of experimental period, geographic region, environmental parameters, and cultural practices (de Vries and Dubois, 1990; Fuchs, 1994; Gammon and McFadden, 1979; Hanan and Grueber, 1987; Holley, 1969; Johansson, 1979; Obiol and Cardus, 1974; Raviv et al., 1993). Most of these studies on rootstock performance have paid more attention to flower yield (number per plant) than other plant response parameters (Cabrera, 2002). Also, little research has been conducted on stenting-propagation of domestic roses in Korea. This study was carried out to investigate the effect of rootstock on the growth and early yield of stenting-propagated domestic cut roses.

\section{Materials and Methods}

\section{Plant Materials}

Plant materials, grown in a commercial rose farm (Dowon Rose Farm, Gimhae, Korea), consist of flowering stems with full-grown leaves and just opening flowers. After normal harvesting, each individual stem was kept apart and cut into sections, each with a five-leaflet leaf and a dormant bud. First grade flowering shoots were harvested at the stage when two sepals were loosely open the flower bud (Jensen and Hansen, 1971). A domestic standard type 'Pink Aurora' and a spray type 'Yellow King' were used in this study. The softwood material as a scion was harvested at a stage when leaves were well developed and prickles could be broken off easily (van de Pol et al., 1986).

\section{Stenting and Treatments}

Scions were grafted onto cuttings either Rosa indica 'Major', Rosa multiflora 'Chille Wonye No. 1', Rosa multiflora 'K-1', or Rosa multiflora 'Burr' as the rootstock. The rootstock materials were obtained from the National Institute of Horticultural and Herbal Science, Suwon, Korea. For each rootstock, a piece of a single internode without a bud was used. The rootstock cuttings were removed of all leaves and buds. Top of the rootstock internodes and the basal part of the scions were held together to simultaneously cut at an angle of $45^{\circ}$ for ease of grafting. For a good development of the graft, the scion-rootstock partners were in close contact each other by combining the cut surfaces. Scion-rootstock unions were stuck in rockwool cubes $(5 \mathrm{~cm} \times 5 \mathrm{~cm} \times 5 \mathrm{~cm}$, Delta, Grodan, Denmark) and were placed on a misted glasshouse bench in Gyeongsang National University, Jinju, Korea. Grafted plants were transplanted into rockwool slabs $(10 \mathrm{~cm} \times 15 \mathrm{~cm} \times 100$ $\mathrm{cm}, \mathrm{UR}$, Korea) at 56 days after stenting. At 73 days after transplanting all shoots were bent (arched) to promote production of vigorous new basal shoots. For prevention of powdery mildew and aphids, chemicals were sprayed weekly.

\section{Experimental Conditions}

A nutrient solution was supplied daily through an arrow dripper (Golden Drip 8, Shinhan Farm Industry, Masan, Korea) at 7:00, 9:00, 11:00, 13:00, 15:00, 17:00, and 19:00 O'clock for three minutes each time. About $605 \mathrm{~mL}$ solution per plant was supplied daily, and a constant nutrient and water status in the root zone were maintained. The composition of the nutrient solution was based on the formulation by the Aichi-ken Hort. Expt. Station, Japan. The $\mathrm{pH}$ and electrical conductivity (EC) of the nutrient solution supplied were 5.8 and $1.2 \mathrm{mS} \cdot \mathrm{cm}^{-1}$, respectively. Mean daily air temperature and relative humidity (RH) measured in the glasshouse during the experimental period by a digital thermometer (Thermo Recorder TR-72U, T\&D Corp., Japan) were $24.2^{\circ} \mathrm{C}$ and $72.4 \%$.

\section{Growth Measurements}

For evaluation of the stenting materials as affected by the rootstock, percent rooting, shoot length, stem diameter, number of roots, and length of the longest root were measured at 56 days after stenting, prior to transplanting. For the evaluation of early cut flower quality and productivity, plant growth and flower quality were evaluated from the first batch harvest during the period of six months (from 
October 2010 to April 2011). Mean stem length, mean stem diameter, mean number of five-leaflet leaves per stem, mean flower width, number of flowers per stem, mean stem fresh weight, and total yield were measured at 183 days after transplanting. The propagation experiment included two cultivars and 20 plants per treatment with three replications. The growth experiment included 10 plants per treatment with three replications.

\section{Statistical Analysis}

Data collected were analyzed for statistical significance by the SAS (Statistical Analysis System, V. 9.1, Cary, NC, USA) program. The experimental results were subjected Duncan's multiple range tests.

\section{Results and Discussion}

Tables 1 and 2 show the effect of rootstock on the rooting and growth of cut roses 'Pink Aurora' and 'Yellow King' measured at 56 days after stenting, just prior to transplanting. Rooting (70\%) was the greatest in the 'Pink Aurora' grafted on the rootstock $R$. indica 'Major' (Table 1). The 'Pink Aurora' grafted on the rootstock $R$. multiflora 'Chille Wonye No. 1', R. multiflora 'K-1', and $R$. multiflora 'Burr' showed a 16.6, 5, and 8.3\% rooting, respectively. Shoot length, stem diameter, number of roots, and length of longest root of 'Pink Aurora' were not significantly affected by the rootstock. In 'Yellow King', rooting was the greatest in plants grafted on the rootstock $R$. indica 'Major' (70\%), followed by the rootstock $R$. multiflora 'Burr' (20\%), R. multiflora 'Chille Wonye No. 1', and then $R$. multiflora 'K-1' (15\%) (Table 2). Shoot length $(9.7 \mathrm{~cm})$ was the greatest in the 'Yellow King' grafted on the rootstock $R$. indica 'Major'. Stem diameter $(5.7 \mathrm{~mm})$ was the greatest in the 'Yellow King' grafted on the rootstock $R$. multiflora 'Chille Wonye No. 1'. Number of roots and length of longest root were not significantly affected by the rootstock.

Stenting propagation for cut roses is difficult to use, because as Bredmose and Hansen (1995) reported, a fairly low percentage of plants survive as compared with cutting propagation. Physiologically, stenting is more complicated than cutting propagation, since formation of the graft union must occur simultaneously with rooting and there are interactions with photosynthesis, root formation, and bud development (van de Pol et al., 1986). According to Dole and Gibson (2006), cuttings produce wound-induced roots after cutting harvest. As soon as the cutting is severed, the outer cells die, forming a protective layer of necrotic cells and suberin. The living cells underneath the protective layer begin to divide to form callus in four steps and roots usually emerge from the callus, but rooting and callus formation are two independent processes. Meanwhile, stages

Table 1. Effect of rootstock on the rooting and growth of cut roses 'Pink Aurora' measured at 56 days after stenting, just prior to transplanting.

\begin{tabular}{lccccc}
\hline Rootstock & $\begin{array}{c}\text { Rooting } \\
(\%)\end{array}$ & $\begin{array}{c}\text { Shoot length } \\
(\mathrm{cm})\end{array}$ & $\begin{array}{c}\text { Stem diameter } \\
(\mathrm{mm})\end{array}$ & $\begin{array}{c}\text { No. of } \\
\text { roots }\end{array}$ & $\begin{array}{c}\text { Length of longest } \\
\text { root }(\mathrm{cm})\end{array}$ \\
\hline R. indica 'Major' & $70.0 \mathrm{a}$ & $12.1 \mathrm{a}$ & $5.5 \mathrm{a}$ & $6.2 \mathrm{a}$ & $7.5 \mathrm{a}$ \\
R. multiflora 'Chille Wonye No. 1' & $16.6 \mathrm{~b}$ & $15.3 \mathrm{a}$ & $6.3 \mathrm{a}$ & $7.5 \mathrm{a}$ & $8.3 \mathrm{a}$ \\
R. multiflora 'K-1' & $5.0 \mathrm{~b}$ & $7.4 \mathrm{a}$ & $3.8 \mathrm{a}$ & $6.5 \mathrm{a}$ & $4.8 \mathrm{a}$ \\
R. multiflora 'Burr' & $8.3 \mathrm{~b}$ & $8.0 \mathrm{a}$ & $3.9 \mathrm{a}$ & $5.5 \mathrm{a}$ & $4.6 \mathrm{a}$ \\
\hline
\end{tabular}

${ }^{\mathrm{z}}$ Mean separation within columns by Duncan's multiple range test at $p=0.05$.

Table 2. Effect of rootstock on the rooting and growth of cut roses 'Yellow King' measured at 56 days after stenting, just prior to transplanting.

\begin{tabular}{lccccc}
\hline Rootstock & $\begin{array}{c}\text { Rooting } \\
(\%)\end{array}$ & $\begin{array}{c}\text { Shoot length } \\
(\mathrm{cm})\end{array}$ & $\begin{array}{c}\text { Stem diameter } \\
(\mathrm{mm})\end{array}$ & $\begin{array}{c}\text { No. of } \\
\text { roots }\end{array}$ & $\begin{array}{c}\text { Length of longest } \\
\text { root }(\mathrm{cm})\end{array}$ \\
\hline R. indica 'Major' & $70.0 \mathrm{a}$ & $9.7 \mathrm{a}$ & $5.1 \mathrm{~b}$ & $5.4 \mathrm{a}$ & $7.9 \mathrm{a}$ \\
$R$ multiflora 'Chille Wonye No. 1' & $16.6 \mathrm{~b}$ & $6.0 \mathrm{ab}$ & $5.7 \mathrm{a}$ & $4.4 \mathrm{a}$ & $7.5 \mathrm{a}$ \\
$R$ multiflora 'K-1' & $15.0 \mathrm{~b}$ & $4.9 \mathrm{~b}$ & $5.1 \mathrm{~b}$ & $5.7 \mathrm{a}$ & $7.0 \mathrm{a}$ \\
$R$ multiflora 'Burr' & $20.0 \mathrm{~b}$ & $5.9 \mathrm{ab}$ & $4.8 \mathrm{~b}$ & $3.9 \mathrm{a}$ & $7.1 \mathrm{a}$ \\
\hline
\end{tabular}

\footnotetext{
${ }^{\mathrm{z}}$ Mean separation within columns by Duncan's multiple range test at $p=0.05$.
} 
of the graft union formation are divided by 1) lining up of vascular cambia of the rootstock and scion, 2) wound healing response, 3) callus bridge formation, 4) cambium formation, and 5) vascular tissue formation (Hartmann et al., 2010). In this study, although rootstock $R$ indica 'Major' was the most effective for rooting in both 'Pink Aurora' and 'Yellow King'. In this study successfully stenting propagated plants all seemed to be grafted first and rooted simultaneously or later. Therefore, no rootstock cuttings without successful grafting were observed to have successful rooting, but they rather died with a change in color into brown. The reason for the most prompted stenting on the rootstock $R$. indica 'Major' is not clear in terms of which developmental stages was promoted in rooting of the rootstock or graft union between the scion and this rootstock. Unfortunately, treatments for rooting of rootstocks without grafting were not included in this study, and therefore, the rooting potentials of the rootstocks and/or interactions between the scions and rootstocks could not be assessed. Many researchers reported that an interaction between the scion and the rootstock exists resulting in high vigor of the root system and greater water and mineral uptake leading to increased yield and fruit enhancement (Bersi, 2002; Ioannou et al., 2002; Kacjan-Marsic and Osvald, 2004).

Tables 3 and 4 show the effect of rootstock on the overall growth of cut roses 'Pink Aurora' and 'Yellow King' grown for about six months after transplanting stenting-propagated plants. In 'Pink Aurora', mean stem length, mean stem diameter, mean number of five-leaflet leaves per stem, and mean stem fresh weight were not significantly affected by the rootstock (Table 3). Mean stem length, mean flower width, mean stem diameter, and mean stem fresh weight of 'Yellow King' were similar in the plants grafted onto the rootstock $R$. indica 'Major' and $R$. multiflora 'Burr' (Table 4). Mean number of five-leaflet leaves per stem of 'Yellow King' was not significantly affected by the rootstock. Rose rootstocks have been reported to affect flower stem length (Han et al., 1994; Gerardo, 2007). In this study although there was no interaction between the effect of the rootstock on rooting (Tables 1 and 2) and the degree of the effect of the rootstock on flower stem length (Tables 3 and 4), cut flower yield was affected by the rootstock (Tables 5 and 6). In cut roses, the flower quality and yield are separate, but dependent, parameters, and usually these two are expressed in an inversely proportional pattern when the total photosynthate is the same, as can be observed in the relationship between the quality and yield of many cut rose cultivars grown in summer and winter seasons. Therefore, high yield is not always accompanied with better quality when the total photosynthate is the same which seemed to be the case in this study (Tables 5 and 6). $\mathrm{Hu}$ (2001) also observed a strong negative correlation between flower quality (either shoot length or shoot weight) and shoot or plant density, especially

Table 3. Effect of rootstock on the growth of cut roses 'Pink Aurora' grown for about six months.

\begin{tabular}{lcccc}
\hline Rootstock & $\begin{array}{c}\text { Mean stem } \\
\text { length }(\mathrm{cm})\end{array}$ & $\begin{array}{c}\text { Mean stem } \\
\text { diameter (mm) }\end{array}$ & $\begin{array}{c}\text { Mean no. of five-leaflet } \\
\text { leaves per stem }\end{array}$ & $\begin{array}{c}\text { Mean stem } \\
\text { fresh wt. (g) }\end{array}$ \\
\hline R. indica 'Major' & $50.3 \mathrm{a}^{\mathrm{z}}$ & $4.7 \mathrm{a}$ & $1.7 \mathrm{a}$ & $34.4 \mathrm{a}$ \\
R. multiflora 'Chille Wonye No. 1' & $46.2 \mathrm{a}$ & $4.4 \mathrm{a}$ & $2.5 \mathrm{a}$ & $29.8 \mathrm{a}$ \\
R. multiflora 'K-1' & $45.7 \mathrm{a}$ & $4.8 \mathrm{a}$ & $2.0 \mathrm{a}$ & $38.1 \mathrm{a}$ \\
R. multiflora 'Burr' & $46.5 \mathrm{a}$ & $4.4 \mathrm{a}$ & $2.3 \mathrm{a}$ & $30.3 \mathrm{a}$ \\
\hline
\end{tabular}

${ }^{\mathrm{z}}$ Mean separation within columns by Duncan's multiple range test at $p=0.05$.

Table 4. Effect of rootstock on the growth of cut roses 'Yellow King' grown for about six months.

\begin{tabular}{|c|c|c|c|c|c|c|}
\hline Rootstock & $\begin{array}{c}\text { Mean } \\
\text { stem length } \\
(\mathrm{cm})\end{array}$ & $\begin{array}{l}\text { Mean } \\
\text { flower width } \\
\text { (cm) }\end{array}$ & $\begin{array}{l}\text { Mean stem } \\
\text { diameter } \\
(\mathrm{mm})\end{array}$ & $\begin{array}{c}\text { Mean no. of } \\
\text { five-leaflet } \\
\text { leaves per stem }\end{array}$ & $\begin{array}{l}\text { Mean no. } \\
\text { of flowers }\end{array}$ & $\begin{array}{c}\text { Mean stem } \\
\text { fresh wt. } \\
\text { (g) }\end{array}$ \\
\hline$R$. indica 'Major' & $47.8 \mathrm{ab}^{\mathrm{z}}$ & $11.0 \mathrm{ab}$ & $5.9 \mathrm{ab}$ & $3.3 \mathrm{a}$ & $5.2 \mathrm{ab}$ & $38.4 \mathrm{ab}$ \\
\hline R. multiflora 'Chille Wonye No. 1 ' & $45.6 \mathrm{ab}$ & $10.9 \mathrm{ab}$ & $5.5 \mathrm{ab}$ & $3.5 \mathrm{a}$ & $5.3 \mathrm{ab}$ & $31.4 \mathrm{~b}$ \\
\hline R. multiflora 'K-1' & $43.2 \mathrm{~b}$ & $10.0 \mathrm{~b}$ & $5.1 \mathrm{~b}$ & $3.5 \mathrm{a}$ & $4.5 \mathrm{~b}$ & $33.4 \mathrm{ab}$ \\
\hline
\end{tabular}

\footnotetext{
${ }^{z}$ Mean separation within columns by Duncan's multiple range test at $p=0.05$.
} 
Table 5. Effect of rootstock on the mean flower stem yield by grade and total flower stem yield of cut roses 'Pink Aurora' grown for about six months.

\begin{tabular}{lcccccc}
\hline \multirow{2}{*}{ Rootstock } & \multicolumn{5}{c}{ Mean flower stem yield by grade $(\mathrm{cm})$} & \multirow{2}{*}{ Total yield } \\
\cline { 2 - 5 } & $\geq 80$ & $79-70$ & $69-60$ & $59-50$ & $\leq 50$ & \\
\hline R. indica 'Major' & 0.0 & 0.0 & $3.0 \mathrm{a}$ & $6.5 \mathrm{a}$ & $11.0 \mathrm{a}$ & $20.5 \mathrm{a}$ \\
R. multiflora 'Chille Wonye No. 1' & 0.0 & 0.0 & $0.5 \mathrm{~b}$ & $2.0 \mathrm{~b}$ & $8.5 \mathrm{a}$ & $11.0 \mathrm{~b}$ \\
R. multiflora 'K-1' & 0.0 & 0.0 & $0.0 \mathrm{~b}$ & $0.5 \mathrm{~b}$ & $3.5 \mathrm{a}$ & $4.0 \mathrm{c}$ \\
R. multiflora 'Burr' & 0.0 & 0.0 & $0.0 \mathrm{~b}$ & $0.5 \mathrm{~b}$ & $2.5 \mathrm{a}$ & $3.0 \mathrm{c}$ \\
\hline
\end{tabular}

${ }^{{ }^{z}}$ Mean separation within columns by Duncan's multiple range test at $p=0.05$.

Table 6. Effect of rootstock on the mean flower stem yield by grade and total flower stem yield of cut roses 'Yellow King' grown for about six months.

\begin{tabular}{lcccccc}
\hline \multirow{2}{*}{ Rootstock } & \multicolumn{4}{c}{ Mean flower stem yield by grade $(\mathrm{cm})$} & \multirow{2}{*}{ Total yield } \\
\cline { 2 - 5 } & $\geq 80$ & $79-70$ & $69-60$ & $59-50$ & $\leq 50$ & \\
\hline R. indica 'Major' & $0.0 \mathrm{a}^{\mathrm{z}}$ & 0.0 & $1.5 \mathrm{a}$ & $3.5 \mathrm{a}$ & $6.5 \mathrm{a}$ & $11.5 \mathrm{a}$ \\
R. multiflora 'Chille Wonye No. 1' & $0.0 \mathrm{a}$ & 0.0 & $0.0 \mathrm{~b}$ & $2.5 \mathrm{a}$ & $5.5 \mathrm{a}$ & $8.0 \mathrm{a}$ \\
R. multiflora 'K-1' & $0.0 \mathrm{a}$ & 0.0 & $0.0 \mathrm{~b}$ & $0.5 \mathrm{a}$ & $4.5 \mathrm{a}$ & $5.5 \mathrm{a}$ \\
R. multiflora 'Burr' & $0.5 \mathrm{a}$ & 0.0 & $0.5 \mathrm{ab}$ & $2.0 \mathrm{a}$ & $2.5 \mathrm{a}$ & $5.0 \mathrm{a}$ \\
\hline
\end{tabular}

${ }^{\mathrm{z}}$ Mean separation within columns by Duncan's multiple range test at $p=0.05$.

at high densities. When the density of shoot is low, as in the case of the two weak stocks Hu (2001) used, number of shoots does not significantly affect the shoot length. Safi and Sawwan (2004) studied the effect of the rootstocks $R$ indica Thory 'Major', $R$. canina L. 'Inermis', and $R$. hybrida L. 'Natal Briar' on growth and flower quality of three $R$. hybrida L. cultivars, and reported that regardless of the rootstock, the grafted cultivars were superior to the ownrooted plants for all parameters studied.

Cut flowers of roses are graded into 1st, 2nd, 3rd, 4th, and 5th grades according to their stem length as $\geq 80$, 79-70, 69-60, 59-50, and $\leq 50 \mathrm{~cm}$, respectively (Tables 5 and 6). The total yield of 'Pink Aurora' obtained was the greatest in plants grafted onto the rootstock $R$. indica 'Major' (20.5), followed by the rootstock $R$ multiflora 'Chille Wonye No. 1' (11.0), R. multiflora 'K-1' (4.0), and then $R$ multiflora 'Burr' (3.0) (Table 5). The total yield of 'Yellow King' was not significantly affected by the rootstock. In this study, total yield obtained in plants grafted onto the rootstock $R$ indica 'Major' was the greatest in both cultivars.

Rose rootstocks are used for several reasons, including economic aspects of propagation, flower production, flower quality, adaptation to different kinds of soil, and disease resistance (Edwards, 1955). $R$ indica 'Major' used in this study is one of the most popular rose rootstocks for greenhouse cut roses, but the species is also valued for garden roses (Cabrera, 2002; Singh and Chitkara, 1982, 1987). Rootstock $R$. multiflora 'K-1' was introduced from Japan because it produced higher yields than the $R$ manetti, $R$ indica 'Major', and $R$. canina 'Inermis' on which scion cultivars were grafted (Ohkawa, 1986). However, total yield harvested in plants grafted onto the rootstock $R$. multiflora 'K-1' was lower than that in plants grafted on the rootstock $R$ indica 'Major' in this study. High tissue concentrations of calcium and chloride, and boron and chloride were reported on scions growing on $R$. indica 'Major' (Johansson, 1979) and R. multiflora (Byrne and Furuta, 1967), respectively. Such differences in rootstock nutrient uptake and accumulation patterns, particularly in newer recirculating hydroponic production systems or under conditions of poor water quality, could significantly affect rose flower yield and thus deserve research attention (Cabrera, 2001; Raviv et al., 1993). In this study, the effect of the rootstock on inorganic nutrient content of roses was not investigated. Therefore, further studies on the effect of the rootstock on inorganic nutrient content of cut roses are necessary.

In conclusion, rooting was the greatest in the 'Pink Aurora' and 'Yellow King' grafted on the rootstock $R$ indica 'Major'. Overall, the growth of 'Pink Aurora' was not affected by the rootstock. The greatest total yield of 'Pink 
Aurora' was obtained in plants grafted on the rootstock $R$. indica 'Major'. Overall growth of 'Yellow King' was the greatest in plants grafted on the rootstock $R$. multiflora 'Burr'. Total yield of 'Yellow King' was not affected by the rootstock. These results suggest that $R$. indica 'Major' was the most effective rootstock not only for rooting, but also for the early yield and growth for the stenting propagation of these cut roses.

\section{Literature Cited}

Bersi, M. 2002. Tomato grafting as an alternative to methyl bromide in Marocco. Proc. 2002 Annu. Intl. Res. Conf. Methyl Bromide Alternatives and Emissions Reductions, San Diego, CA, USA. p. 3-6.

Bredmose, N. and J. Hansen. 1995. Regeneration, growth and flowering of cut roses cultivars as affected by propagation material and method. Sci. Hortic. 64:103-111.

Byrne, T. and T. Furuta. 1967. Rootstock and chemical composition of roses. HortScience 2:18.

Cabrera, R.I. 2001. Effect of NaCl-salinity and nitrogen fertilizer form on yield and tissue nutrient status of roses. Acta Hortic. 547:255-260.

Cabrera, R.I. 2002. Rose yield, dry matter partitioning and nutrient status responses to rootstock selection. Sci. Hortic. 95:75-83.

de Vries, D.P. and L.A.M. Dubois. 1990. Shoot production of 'Sonia' on hybrid tea rootstock clones of different vigour. Gartenbauwissenschaft 55:268-271.

Dole, J.M. and J.L. Gibson. 2006. Cutting propagation, p. 3-16. In: J.M. Dole and D.J. Hamrick (eds.). Propagation basics. Ball Publishing, Batavia, IL.

Edwards, R.E. 1955. A survey of rootstocks for roses. University of Nottingham, Nottingham, UK. p. 137.

Fuchs, H.W.M. 1994. Scion-rootstock relationships and root behaviour in glasshouse roses, p. 17. In: H.W.M. Fuchs (ed.) The effect of rootstock on bush development and production. PhD Diss. Wageningen Agricultural Univ., Wageningen, The Netherlands.

Gammon, N., Jr. and S.E. McFadden, Jr. 1979. Effect of rootstocks on greenhouse rose flower yield and leaf nutrient levels. Commun. Soil Sci. Plant Anal. 10:1171-1184.

Gerardo, M. 2007. Rose propagation, p. 44-45. In: M. Gerardo (ed.). Cut rose cultivation around the world. Schreurs, De Kwalcel, The Netherlands.

Han, Y.Y., S.K. Chung, and B.H. Kwack. 1994. Effect of different rootstocks on the productivity and quality of cut roses grown in greenhouse. RDA J. Agri. Sci. Hort. 36:453-459.

Hanan, J.J. and K.L. Grueber. 1987. Understocks, p. 29-34. In: R.W. Langhans (ed.). Roses. Roses Incorporated, Haslett, MI, USA.

Hartmann, H.T., D.E. Kester, F.T. Davies, and R. Geneve. 2010.
Hartmann and Kester's plant propagation: Principles and practices, p. 425. In: H.T. Hartmann, D.E. Kester, F.T. Davies, and R. Geneve. (eds.). Principles of grafting and budding. 8th ed. Pearson Higher Education, Harlow, UK.

Holley, W.D. 1969. Understocks, p. 78-92. In: J.W. Mastalerz and R.W. Langhans (eds.). Roses. Pennsylvania Flower Growers, NY State Flower Growers Association and Roses Inc., Haslett, MI. USA.

$\mathrm{Hu}, \mathrm{X}$. 2001. Growth and productivity of cut rose as related to the rootstock, p. 22. In: X. Hu. (ed.). Growth of rose cultivar 'Frisco' as affected by rootstocks in the knot-growing system. $\mathrm{PhD}$ Diss. Wageningen Agricultural Univ., Wageningen, The Netherlands.

Ioannou, N., M. Ioannou, and K. Hadjiparaskevas. 2002. Evaluation of watermelon rootstocks for off-season production in heated greenhouses. Acta Hortic. 579:501-506.

Jensen, H.E.K. and W. Hansen. 1971. Keeping quality of roses. I. The influence of the stage of maturity at the time of harvest on the longevity and opening of the flower. Danish J. Plant and Soil Sci. 75:591-596.

Johansson, J. 1979. Leaf composition of flowering shoots from different greenhouse rose cultivars as influenced by rootstock and season. Acta Agric. Scand. 29:85-92.

Kacjan-Marsic, N. and J. Osvald. 2004. The influence of grafting on yield of two tomato cultivars (Lycopersicon esculentum Mill.) grown in a plastic house. Acta Agri. Slovenica 83:243-249.

Niu, G. and D.S. Rodriguez. 2008. Responses of growth and ion uptake of four rose rootstocks to chloride- or sulfate-dominated salinity. J. Amer. Soc. Hort. Sci. 133:663-669.

Obiol, R. and J. Cardus. 1974. Influence of rootstocks on rose culture. Acta Hortic. 43:197-200.

Ohkawa, K. 1980. Cutting-grafts as a means to propagate greenhouse roses. Sci. Hortic. 13:191-199.

Ohkawa, K. 1986. Rootstock native to Japan. Acta Hort. 186:61-66.

Park, Y.G. and B.R. Jeong. 2010a. Effect of plug cell size used in propagation on the growth and yield of stenting-propagated cut roses. Hort. Environ. Biotechnol. 51:249-252.

Park, Y.G. and B.R. Jeong. 2010b. Effect of topophysis and uniting method of rootstock and scion on rooting and subsequent growth of stenting-propagated (cutting-grafted) roses. Kor. J. Hort. Sci. Technol. 28:456-461.

Park, Y.G. and B.R. Jeong. 2012a. Effect of light intensity during stenting propagation on rooting and subsequent growth of two rose cultivars. Flower Res. J. 20:228-232.

Park, Y.G. and B.R. Jeong. 2012b. Growth and early yield of stenting-propagated domestic roses are not affected by cytokinins applied at transplanting. Flower Res. J. 20:55-63.

Raviv, M., S. Medina, Y. Shamir, S. Gil'ad, O. Duvdevani, Y. Shor, and R. Schayer. 1993. Clonal variability among Rosa indica rootstocks: Morphology, horticultural traits and productivity of scions. Sci. Hortic. 53:141-148.

Safi, M.I. 2005. Flower production related to re-blooming time 
of three Rosa hybrida cultivars in response to rootstock type. ScienceAsia 31:179-181.

Safi, M.I. and J.S. Sawwan. 2004. Growth and flower quality of three Rosa hybrida L. cultivars in response to rootstock. Mutah Lil Buhuthwad Dirasat 19:11-24.

Singh, B.P. and S.D. Chitkara. 1982. Effect of different salinity and sodicity levels on establishment and bud take performance of various rose rootstocks. Haryana J. Hort. Sci. 11:204-207.

Singh, B.P. and S.D. Chitkara. 1987. Effect of different salinity levels on water potential and proline content in leaves of various rose rootstocks. Indian J. Hortic. 44:265-267.

van de Pol, P.A. and A. Breukelaar. 1982. Stenting of rose: A method for quick propagation by simultaneously cutting and grafting. Sci. Hortic. 17:187-196.

van de Pol, P.A., M.H.A.J. Joosten, and H. Keizer. 1986. Stenting of roses, starch depletion and accumulation during the early development. Acta Hortic. 189:51-59. 